\title{
THE EFFECTS OF HIGHER ADMISSION STANDARDS ON NCAA STUDENT-ATHLETES: AN ANALYSIS OF PROPOSITION 16
}

\author{
Joshua Price*
}

Cornell University

\footnotetext{
* Direct correspondence to Joshua Price, Cornell University, Department of Policy Analysis and Management, 385
} Ives Hall East, Ithaca, NY 14853 jap224@cornell.edu phone: (607) 229-5590 
The Effects of Higher Admission Standards on NCAA Student-Athletes:

An Analysis of Proposition 16

\begin{abstract}
This study examines the effect of an increase in minimum admissions standards on college enrollment and graduation rates of student-athletes. In 1996, the NCAA enacted Proposition 16, which increased the admission standards for freshmen student-athletes at Division I schools in an effort to improve graduation rates. Results indicate that Proposition 16 increased graduation rates significantly for black student-athletes, and had no significant impact on graduation rates for white student-athletes. Results also indicate that graduation rates declined for black student-athletes at Division II schools, which may be driven by students transferring to Division I. As a result of the higher admission standard Division I schools changed recruiting patterns and relied less on freshmen student-athletes, particularly black student-athletes, to fill scholarships. Even though fewer black freshmen student-athletes enrolled in Division I schools, the overall number of black student-athletes did not change, suggesting that greater proportion of transfer students into Division I schools were black.
\end{abstract}

Keywords: NCAA, Eligibility requirements, Enrollment, Graduation, Proposition 16 
In January 1989, Georgetown was scheduled to play Boston College in a men's basketball game. Right before tip-off, future Hall of Fame coach John Thompson, in protest of a NCAA proposal, walked off the court and into the locker room. The proposal, which caused the coach of one of the nation's best basketball teams to protest, used standardized test scores to determine eligibility for student-athletes. John Thompson, among others, felt that such an NCAA policy would disadvantage black student-athletes. Thus leading to the question, did NCAA policy which relied on standardized test score to determine initial eligibility have differential impacts by race?

The National Collegiate Athletic Association (NCAA) asserts the pursuit of academic excellence as one if its core values and objectives. Due to this, the NCAA has passed legislative policies which established eligibility requirements for first time freshmen and continuing student-athletes ${ }^{1}$. In the early 1980's, the NCAA began to use standardized test scores, in addition to high school GPA's, as a requirement for freshmen eligibility. In the late 1980's, discussion began about increasing the initial eligibility standard through requiring a higher test score, GPA, and number of core classes taken in high school. It continued until the early 1990's when the NCAA raised its admission standard requiring either higher test scores or a higher GPA for freshmen student-athletes. Again raising the debate of whether relying on these measures of ability disadvantages minority students more than non-minority student-athletes.

In this study, I examine the effects of changes in the NCAA's policy from the viewpoint of the university or college. The NCAA policy raised the admission standards for studentathletes who attended schools which were a member institution of the NCAA. Student-athletes must abide by the NCAA standards to participate in inter-collegiate athletics, regardless of their school's admission standard. Thus, the question that I address is how does increasing the

\footnotetext{
${ }^{1}$ For a comprehensive review of NCAA eligibility policies see Covell \& Barr (2001).
} 
admission standard change the type of students that those schools admit. I also test whether Proposition 16 was effective in its goal of increasing the graduation rate of student-athletes.

\section{Proposition 48}

The first policy enacted by the NCAA that altered admission requirements for studentathletes was Proposition 48. Previously, only a 2.0 high school GPA was required for students to be eligible to participate in inter-collegiate athletics. Proposition 48 included standardized test scores to determine initial eligibility in order to set a national standard to "level the playing field" of academic recruiting standards. Beginning with Division I schools in 1986, potential studentathletes needed to achieve a 700 combined score on the SAT (17 ACT) in addition to a 2.0 high school GPA (See Figure 1, top panel). By meeting these standards, students became eligible to practice, compete, and receive athletic financial aid. Proposition 48 was later implemented among Division II schools beginning with the 1988-1989 academic school year.

The NCAA released a series of reports analyzing the effects of Proposition 48 on 6-year graduation rates (NCAA Research Report Series 01, 1990). The findings indicate that in the three years prior to the implementation of the policy, graduation rates averaged 52 percent for all student-athletes at Division I schools. For the first cohort subject to the regulations of Proposition 48, graduation rates increased to 57 percent and continued to rise to 59 percent for the entering cohort of 1988. Some of the largest increases in completion rates were found among minority students. Graduation rates rose 8 percentage points for African-American students and 11 percentage points for Hispanic students, up to 44 and 50 percent respectively. From these results the NCAA concluded that increasing admission standards led to significantly higher graduation rates. 
While the focus of Proposition 48 was to establish a national standard of admissions based on indicators of college success, requiring a benchmark score on the SAT might disadvantage minorities more so than whites. The total number of African-American freshmen student-athletes went from 3,724 in 1985 to 3,041 in the first year after Proposition 48, an 18.3 percent decrease. In spite of this significant increase, the total number of African-Americans admitted in 1986 who graduated within 6 years was virtually identical to the 1985 cohort $(1,334$ compared to 1,337 respectively). Examining recruiting behavior of Division IA football programs, Heck and Takahashi (2006) find that freshmen enrollment decreased after Proposition 48 and that there was an increase in the number of transfer students.

Overall, analyses of Proposition 48 indicate that establishing an SAT score cut-off in conjunction with a required high school GPA increased graduation rates of those admitted to Division I schools. African-Americans and Hispanics saw the greatest increase in 6-year graduation rates. However, as a result of the policy, the proportion of freshmen student-athletes who were minorities decreased dramatically.

\section{Proposition 16}

With continued concern about admitting students who were not prepared to succeed in college and graduate, the NCAA enacted Proposition 16, which took effect in the fall of 1996 among Division I schools, and did not apply to Division II schools. Similar to its predecessor, Proposition 16 increased the admission requirement of high school GPA and standardized test scores, but differed by using a sliding scale. The sliding scale required a student who earned a 2.00 GPA to achieve at least a 1080 on the SAT, or it required a student who scored an 820 on 
the SAT to receive a $2.50 \mathrm{GPA}$, or a linear combination of the two (see Figure 1, bottom panel) ${ }^{2}$. Those who did not meet the new sliding scale standard but still met the prior requirements were still eligible for athletic scholarships from Division II schools, but no longer from Division I.

Critics of Proposition 16 claimed that this policy would have differential effects on specific racial and ethnic groups because it placed more weight on the SAT for admission into a Division I school. An NCES study showed that, among 1992 high school graduates who applied to college and took the SAT (or ACT), only 46.4 percent of Black students and 54.1 percent of Hispanic students meet the standard set by Proposition 16, compared to 67 percent of White and Asian students (NCES, 1995). Other studies have shown that blacks score significantly lower on the SAT (Hoffman \& Lowitzki, 2005; Fleming, 2002; Camara \& Schmidt, 1999). In the book, Black-White Test Score Gap ( Jencks \& Phillips, 1998), Vars and Bowen find evidence that the predictive power of SAT scores for Blacks is less than for Whites. Fleming (2002) asserts that while the SAT is a better predictor for Blacks who attend Historically Black Colleges and Universities (HBCU), it is a poor predictor of college success for Black males who attend a nonHBCU. Due to the differential performance between minorities and non-minorities on standardized tests and lower predictive power of college performance, opponents of Proposition 16 brought a lawsuit against the NCAA claiming that Proposition 16 violated the Civil Rights Act of 1964 (Title VI) by discriminating against minorities (Cureton v. NCAA). While the courts originally ruled Proposition 16 to violate Title VI, the ruling was later overturned in Circuit Court because, according to the ruling, the NCAA was not subject to the Title VI's discriminatory effects regulations since they did not receive federal funding.

\footnotetext{
${ }^{2}$ Beginning in 1996 the SAT rescaled the scoring of the verbal and math section such that a 700 in 1995 was equivalent to an 820 in 1996.
} 
The NCAA's own research examining the effects of Proposition 16 focuses primarily on the increases in graduation rates, comparing the year before the policy to the first year after ${ }^{3}$. Their study indicates that student-athletes matriculating under the guidelines set by Proposition 16 experience a two percentage point increase in graduation rates, to an all-time high of 62 percent. They break down the effect and show that blacks in men's basketball increased from 35 to 41 percent. Division I-A black football players also had an increase in graduation rates, from 46 to 49 . Yet white student athletes in men's basketball and football were one percentage point lower than the 1995 graduation rate. In this report they also note that as a result of the policy, the proportion of African American student-athletes in the freshmen class fell, particularly in men's basketball and football, by 2.9 and 3.7 percentage points respectively. A managing director of research for the NCAA said, "though the research indicates fewer black student-athletes overall, those in the system graduated at a higher rate than previous cohorts" (NCAA News 2003). Yet comparisons across just two years do not account for trends that may drive the findings. Thus a more rigorous analysis is needed to identify the true effects of the change in the policy.

\section{Hypotheses}

There are two specific hypotheses that I test in this study. First, higher admission standards based on a standardized test score and GPA will cause Division I schools to admit fewer freshmen student-athletes, particularly minorities, and enroll more transfer studentathletes. Second, the higher admission standard will increase graduation rates for all studentathletes at Division I schools, with minority-student athletes experiencing a greatest increase in graduation rates.

\footnotetext{
${ }^{3}$ http://www.ncaa.org/wps/ncaa?ContentID=10678
} 
When admitting freshmen student-athletes, athletic departments seek to maximize a combination of athletic and academic ability of student-athletes. The specific combination is decided by each school, since it is certainly the case that some schools place more weight on the academic ability of student-athletes. However, they face two constraints. First, student-athletes must meet a school minimum athletic ability to be offered an athletic scholarship. Second, student-athletes must meet the higher of two academic eligibility standards. The first is the standard set by the institution that all students must meet in order to be admitted. This varies widely by institution and is not always an explicit benchmark publicized by individual schools. The second is the standard set by the NCAA that all student-athletes must meet to be eligible. Many schools admit student-athletes through a special admission process, and often time these students have significantly lower test scores than the student body population. An investigation by the Atlanta Journal Constitution reported that at Clemson University, UCLA, Rutgers University, Texas A\&M University, Louisiana State University and the University of Georgia more than half of all student-athletes are special admits, with University of Georgia having 73.5 percent of all student-athletes admitted this way (Knobler, 2008). Thus, it very well may be that even at schools with higher admission standards, the NCAA academic requirement is the binding constraint due to special admissions. When admitting transfer student-athletes, schools face a different admission standard based on grades in college courses and not on high school GPA and test scores. Between freshmen and upper class athletes, schools try to fill all scholarships available in a given year.

For a Division I school to fill their allotted number of scholarships they could have either reduced the athletic ability required to be offered a scholarship or they could have given scholarship offers to non-freshmen student-athletes. It is unlikely that athletic departments would 
reduce the athletic ability required for scholarship recipients, due to possible returns to the athletic program and the University for having a successful athletic program. These returns include higher publicity, increases in SAT scores sent to the school (Pope \& Pope, 2006), a better student environment, and increases in alumni donations to the school (Tucker, 2004, Brooker \& Klastorin, 1981). Rather than admit student-athletes with lower athletic ability, it is expected that athletic departments would turn to transfer students to fill the scholarships available ${ }^{4}$. Thus, it is hypothesized that Division I schools changed recruiting patterns by relying more on transfer student-athletes and less on first time freshmen student-athletes to fill scholarships after the implementation of the policy.

Furthermore, it is hypothesized that with higher admission standards, graduation rates should have increased at Division I schools. With higher standards, better prepared students were admitted, and as a result of better prepared students, graduation rates would have increased. This would correspond with the NCAA's study examining the effect of Proposition 48 (NCAA Research Report Series 01, 1990) as well as with other research stating that high school GPAs and standardized test scores are predictors of academic success at college (Burton \& Ramist, 2001; Fleming, 2002; Betts \& Morrell, 1999).

However, the hypothesized effect of the policy on graduation rates for Division II schools is ambiguous. Graduation rates would increase if the student-athletes who no longer qualified for Division I schools academically were admitted to Division II schools and had higher probabilities of graduating than other student-athletes at Division II schools. Or it may be the case that these individuals were at the bottom of the ability distribution of Division I schools, and when they enrolled in Division II schools, they remained at the bottom of the distribution, which would decrease the graduation rate at their Division II school. It is possible that although these

\footnotetext{
${ }^{4}$ In addition to transfer students, athletic departments could also offer scholarships to walk-ons.
} 
individuals did not achieve the required SAT score or GPA for Division I eligibility they still had the ability to be successful at college, and they possessed the athletic ability to compete in Division I athletics. Thus, they may spend enough time at a Division II school to meet the requirements to transfer to a Division I school, in which they would then be counted as a noncompleter, and graduation rates would decrease at the Division II school. Therefore, I will rely on the data to determine the direction of the effect of the policy on Division II graduation rates.

\section{Data}

The data for the present analysis comes from the National Collegiate Athletic Association's Graduation Report, which publishes enrollment and graduation rates for each member institution as mandated by the Student Right to Know Act. Individual institutions submit the data to the NCAA where it is reviewed by research staff. After a review by the NCAA a report is published and each institution verifies the report. The Graduation Report is found on the NCAA website (www.ncaa.org) and was converted for the present study into a panel data set that consists of institutional level data. Five entering freshmen cohorts were used for this analysis, three cohorts prior to Proposition 16 (1993-1995) and two cohorts after Proposition 16 (1996-1997). 1993 is the first year that institutional level data was made available to the public. Although data is available for cohorts past 1998, the NCAA implemented a program known as Academic Progress Reports which required student-athletes to complete a specific fraction of their degree by each year. Punishments were also established for schools who received poor Academic Progress ratings, and such punishments could result in loss of allotted scholarships. Thus, schools might change the effort put forth to aid student-athletes towards completing a degree and graduation. While this policy did not take effect until 2005, any changes that 
institutions implemented in response to this policy would affect the 6-year graduation rate of the 1998 entering cohort. In addition to this policy change, the NCAA also was subjected to stricter confidentiality requirements by the Department of Education which caused them to suppress more data when cell sizes were small. Therefore, using more than the two years after the policy might not be able to cleanly identify the effects of Proposition 16 without

Proposition 16 only applied to those student-athletes who participated in Division I schools and not to those who participated in Division II. The distinction between divisions is made by criteria set by the NCAA based on number of scholarship athletes, number of sports offered, and other factors. The data contains 306 schools in Division I and 288 schools in Division II. Furthermore, the policy only affected student-athletes participating in intercollegiate athletics and defines student-athletes as full-time students who receive athletic aid ${ }^{5}$. Therefore, those schools who do not offer athletic aid (Division III institutions, Ivy League schools, and U.S. Military Academies) are excluded from this analysis.

To protect the privacy of individuals, the NCAA suppresses data when the number of enrolled student-athletes or number of student-athletes who graduate is one or two. If the number of enrolled student-athletes is suppressed, then the graduation rate is also not reported. When this is the case, I impute the number of enrollees equal to one and the graduation rate is still reported as missing. However, if the number enrolled is greater than two and the number of graduates is one or two, the graduation rate is not reported, but the number of enrollees is still provided. When this is the case, an imputed graduation rate is used such that the number of student-athlete

\footnotetext{
${ }^{5}$ Athletic aid is defined as any grant, scholarship, tuition waiver, or any other financial assistance from the college or university based on a student's athletic ability.
} 
graduates is equal to one ${ }^{6}$. By using this imputation method, the results on enrollment and graduation rate should be seen as a lower bound.

The first key variable of interest is the number of first time freshmen student-athletes who enroll at a given institution. As shown on Table 1, the average number of freshmen studentathletes at Division I and II schools increased from 1993 to 1997. These increases over the years are also present for white student-athletes at both divisions. However, the average number of black student-athletes decreased at Division I schools and slightly increased at Division II schools over the time span. Division I averages more student-athletes per school than Division II and both types of schools experienced an increase in the average number of enrolled studentathletes since 1993. The total number of student-athletes at a school can increase for one of two reasons, the number of allotted scholarships can be increased by the NCAA or schools can divide a scholarship between multiple individuals.

It may be thought that it is the "big-time" sports that would be most affected by the stricter admission policies, namely football and basketball. Thus, examining individually would be ideal to see if the higher admission standard effected sports differently. The data does not provide a continuous measure of the number of freshmen student-athletes by sport. What is provided is enrollment by groups $(1-5,6-10,11-15,16-20$, and more than 20) for certain a few sports and then clumps all other sports into one category. Because of this breakdown, men's football is the only big-time sport that experiences variation between the different categories due to the number of football scholarships allotted. Basketball admits so few freshmen student athletes each year that any change in recruiting will not be detected by the bins that the data provides. Due to the

\footnotetext{
${ }^{6}$ Results do not change significantly when imputing the graduation rate assuming the unreported number is two and imputing the number of enrollees to be equal to two.
} 
clumping of other sports in one category ${ }^{7}$, a comparison between football and other non-big-time sports can be made. Even though many student-athletes may receive special admissions, it is believed that football players are the greatest benefactors of special admissions. This leads to the hypothesis that higher admission standards should affect the enrollment of football participants more than other sport participants.

The other key outcome of interest is 6-year graduation rates, which is defined as the number who graduate within six years divided by the size of the entering cohort at a given institution. This measure of graduation rate is limited by the treatment of transfer students. Students who transfer out of a school while in good academic standing and graduate at another institution are considered dropouts for the initial school. Furthermore, students who transfer into a school are not accounted for with this measure of graduation rate, regardless of whether they graduate or not. One of the strengths, though, of using graduation rates is that it is measured in the same way for student-athletes and students at each institution, thus comparisons can be made between the two types of students Graduation rates for student-athletes are higher among Division I schools than Division II, and both divisions have experienced consistent increases in graduation rates since the 1980 's. Compared to the general student body population, studentathletes in both Division I and Division II schools experience higher graduation rates (see Table 2), and rates have been increasing between 1993 and 1997.

\section{Methods}

Prior to Proposition 16, schools in both Division I and II had the same academic requirements for student-athletes. The treatment in this analysis is the change in admission

\footnotetext{
${ }^{7}$ For men, other sports include all sports except baseball, basketball, football, and track/cross country and for women other sports include all sports except basketball and track/cross country.
} 
standards caused by the policy change of Proposition 16. With the implementation of Proposition 16, only Division I schools experienced an increase in admissions requirements. Prior to the treatment Division I and II schools experienced similar trends in enrollment of student-athletes (See Figure 2). Due to these similar trends prior to the policy change, I am able to identify the effect of the higher admission standards on enrollment of freshmen by using a difference-indifferences (DID) approach, using Division II as a control group. The first difference accounts for changes that occurred within each division. The second difference is between differences in changes of enrollment at Division I and Division II schools ${ }^{8}$.

With the large incentives that schools have for competing in "big time" sports, there is a perception that participants in these sports are most at risk of being affected by a higher admission standard. While the data does not allow for an analysis for number of freshmen student athletes, a discrete choice model will be used to estimate the effects of Proposition 16 on freshmen enrollment in football and other sports. The outcome of interest is enrollment of freshmen student-athletes in the sport and takes on the values of 1 if there are 1-5 recruits, 2 if there are 6-10 recruits, 3 if there are 11-15 recruits, 4 if there are 16-20 recruits, and 5 if there are more than 20 recruits. An ordered probit model will be used because of the ordinal property of the dependent variable. Due to the small cell size of observations when dividing the sample by race, this will only be estimated for all freshmen student-athletes.

A DID approach is also used to examine the effects of Proposition 16 on graduation rates. As shown in Figure 3, there are similar trends prior to 1996 between Division I and Division II. However, a DID approach may not accurately identify the effects of Proposition 16 because there may be characteristics of the institution that can influence graduation rates for all students,

\footnotetext{
${ }^{8}$ To account for individual institutional policies that may have affected enrollment of student-athletes, a third difference was taken between student-athletes and non-athletes. Results are both quantitatively and qualitatively similar.
} 
including student-athletes. For example, a university may implement a program that increases the graduation rate of all the student body, including student-athletes. As shown in Table 2, nonstudent athletes have experienced similar increases in graduation rates before 1996. Thus, to be able to identify the effect of Proposition 16 on graduation rates, a third difference is taken between student-athletes and the general student body. This will difference out any independent effect that an individual institution might have on student-athlete graduation rates.

As shown in Figures 2 and 3, there are general upward trends in both enrollment and graduation rate prior to 1996 . Due to this, a time-trend is included in all specifications to account for these upward trends ${ }^{9}$. It might be thought that there may be different effects among Division IA compared to other Division I schools or between BCS and non-BCS schools. I estimate the models based on these specifications, and the results indicate there are no significant differences among differing classifications within Division $\mathrm{I}^{10}$.

\section{Results}

It was hypothesized that with higher admission standards for first-time freshmen Division I schools would decrease the enrollment of freshmen in the years following the implementation of Proposition 16. Results indicate that the average enrollment of freshmen student-athletes (including all racial and ethnic groups, i.e. white, black, Hispanic, Asian, Native American, and non-resident alien) at Division I schools decreased by 9.9 percent following the policy change (See Table 3, the interaction between Div I * Post yield the effect of the policy change on Division I student-athletes). Analyzing the results by race show that the average enrollment of

\footnotetext{
${ }^{9}$ Additionally, to account for changes in the slope after the policy, a time-trend interacted with a dummy variable is also included. Both specifications are reported in the tables.

${ }^{10}$ These results are available from the author upon request.
} 
white and black freshmen student-athletes decreased by 12.2 and 20.1 percent, respectively ${ }^{11}$. The average enrollment decrease for black student-athletes was nearly twice as large as the effect on white student-athletes. This result provides support for the claim that black student-athletes were disproportionately negatively affected by this policy. To further check the robustness of these findings, a third difference is taken between student-athletes and non-student-athletes, and these results indicate that after the policy change black student-athletes enrollment decreased by over 20 percent at Division I schools (See Table 3).

To further examine the effect of the NCAA policy on enrollment of freshmen studentathletes, the fraction of student-athletes who are freshmen is used as the dependent variable. During the years of analysis, the number of students with athletic scholarships increased, which reflects the ways schools disperse partial scholarships, which may cause the increase in the number of freshmen student-athletes to likewise increase. If this were the case, then the fraction of student-athletes who were freshmen should not change. As presented in Table 4, Division I schools experienced a decrease of 2.8 percent in the fraction of freshmen student-athletes. The effect is being driven by the decreases in the fraction of black student-athletes who are freshmen, a 3.2 percent decrease. Taking a third difference with the fraction of the student-body who are freshmen show that these results are robust. These findings suggest that even if the number of scholarships is increasing over time, the fraction of student-athletes who are freshmen is decreasing after Proposition 16.

There are two groups that should not be affected by this policy and an analysis of these groups can serve as falsification tests. The first of these groups is the total number of studentathletes. Each school is allotted a specific number of scholarships, and a DID estimation should

\footnotetext{
${ }^{11}$ A similar analysis is not done for other races or ethnicities due to small sample size of these groups at individual institutions.
} 
show no change in the total number of scholarship student-athletes. Table 5 shows that there were no significant changes in the total number of student-athletes, particularly no change in the total number of black student-athletes. The measure of total number of student-athletes includes freshmen, thus for the total number of black student-athletes to remain unchanged, there must be an increase in the number of black transfer students to account for the decrease in the number of black freshmen. The other group that should not be affected by this policy is freshmen nonstudent-athletes. As shown in Table 6, there is no significant changes at Division I schools after the policy change (as represented by Div I * Post). These two examples indicate that the policy did not have an affect on groups which were not subject to its requirements.

Focusing on individual sports, football, which has more student-athletes than any other sport, shows similar patterns of reductions in the number of recruits at Division I schools. Average marginal effects from an ordered logit estimation indicate that most of the change occurred from decreases in the probability of enrolling more freshmen recruits at Division I schools (See Table 7). As hypothesized, the policy had no measurable effect on admission of other athletic recruits. These results come with limitations; variation does not come from a change in the number, but only changes across bins. For example, a change in going from 16 to 15 recruits is measured the same as going from 20 to 11 recruits, and a change from 20 to 15 is not picked up by the measurement. Therefore, even though the results suggest a statistically significant change between the categories of football recruits, it is not possible to measure the actual change in number of recruits.

The compilation of these outcomes of enrollment provide evidence that, as a result of higher initial eligibility standards, Division I schools changed their recruiting patterns. They 
relied less on freshmen to fill scholarships, particularly black freshmen, and more on transfer students.

The objective of Proposition 16 was to admit students who were academically prepared to succeed at the institutions they attended. The measure of success that was of primary importance was graduation rate. The difference-in-differences approach indicates that overall graduation rate for student-athletes at Division I schools did not significantly change (See Table 8). (Note that Post represents the effect the policy had on Division II and the interaction of Post and Division I yields the effect on Division I schools). However, Black student-athletes experienced a 7.1 percent increase in graduation rate. But as mentioned before, it is important to difference out other institutional factors that might affect student-athletes graduation rate. As Table 8 shows, graduation rates increased slightly for all students with no significant change for whites or black students at Division I schools after the policy. Thus by taking the third difference, the effects of Proposition 16 can be identified without being confounded by other institutional programs directed at increasing graduation rates. Division I schools only saw a significant change in the graduation rates of black student-athletes, which increased by 7.5 percent (As noted by the coefficient of the triple interaction of Athlete*DivI*Post).

Ex ante, it was unclear what effect the policy would have on the graduation rate of Division II student athletes. It was proposed that it depended on where the non-qualifying students fit in the distribution of the Division II school they attended. This number would suggest that student-athletes who were deemed unprepared to succeed at Division I schools, as s result of their test score and GPA, were unprepared to succeed academically at a Division II school. While this may be the case, I believe there is an better explanation for these results. Nonqualifying students who attended Division II schools possessed the athletic ability to compete at 
Division I schools. Thus once they complete an academic year of college, they are no longer subject to initial eligibility requirements and can transfer into a Division I school based on college performance, and not standardized test scores. These transfer students would then count as non-graduators and as a result the graduation rate would decrease at Division II schools. A back of the envelope calculation shows that the 8 percent decrease in black student-athletes can be caused by an average of 1 student for every two Division II schools to transfer to a Division I school (an increase of 144 transfer students). This calculation shows that a small number of students can cause a significant change, and caution should be used in drawing implications from these results.

\section{Conclusion}

The objective of Proposition 16 was to increase graduation rates at Division I schools by increasing the required grade point average and test scores of entering freshmen student-athletes. The results of this study indicate that these higher standards increased graduation rates for black student-athletes at Division I schools, but had no real effect on the average graduation rates for Division I student-athletes. However, due to higher academic standards required for eligibility, athletic departments relied less on freshmen and more on transfer students to fill scholarships. This is evident in the decline in the number of freshmen enrolled as well as the fraction of student athletes who are freshmen at Division I schools, but no change in the total number of student-athletes.

Opponents of Proposition 16 argued that by relying more on standardized test scores for admittance to Division I schools, minority student-athletes would be affected more so than nonminority student-athletes. This study indicates that enrollment of black freshmen student-athletes 
decreased as a result of the policy. However, the total number of black student-athletes did not decrease, indicating that more black transfer students were recipients of athletic scholarship after Proposition 16.

The question that this study cannot answer, but attempts to shed light on, is, are potential student-athletes better off as a result of this policy? Although this study reports changes in school level enrollment and graduation rates, its inability to track students over time does not allow it to examine choices by individuals. With individual-level data, an analysis can be conducted to examine how Proposition 16 affected the choices of the individual with regards to enrollment, persistence, and graduation.

The other question that needs to be addressed is what standard can or should the NCAA use to determine initial eligibility of freshmen student-athletes? Standardized test scores are a low cost option that has limitations, but what other alternatives are there? It was suggested that the NCAA determine eligibility on a case by case basis, but due to the number of student-athletes this is not at all practical. Recently, many colleges have begun to rely less on the SAT/ACT and some have even dropped it all together (most notably Wake Forest University). The admission process at these schools may serve as useful examples of ways in which a standard could be set without requiring standardized test scores.

All in all, the policies established by the NCAA have attempted to emphasize the academic portion of the student-athlete equation. Graduation rates have continued to rise for student-athletes over the years and are significantly higher than overall student-body graduation rates. However, caution should be used when using only graduation rate as a measure of policy success. As seen with Proposition 16, when only graduation rates are examined, many other 
aspects of the educational process that play an integral role in evaluating the effectiveness of policies may be overlooked. 


\section{References}

Betts, Julian R. and Darlene Morell, 1999. “The Determinants of Undergraduate Grade Point Average." Journal of Human Resources. 34(2): 268-293.

Brooker, George and T.D. Klastorin, 1981. "To the Victors Belong the Spoils? College Athletics and Alumni Giving” Social Science Quarterly. 62(4): 721-734.

Burton, Nancy and Leonard Ramist, 2001. "Predicting Success in College: SAT Studies of Classes Graduating Since 1980.” College Board Research Report No. 2001-2. College Entrance Examination Board, New York.

Camara, Wayne J.; and Amy Elizabeth Schmidt, 1999. “Group Differences in Standardized Testing and Social Stratification.” College Board Report No. 99-5. College Entrance Examination Board, New York.

Covell, Dan \& Carol A. Barr, 2001. "The Ties that Bind.” The Journal of Higher Education. 72(4):414-452.

Dale, Stacy Berg, and Alan Kruger, 2002. "Estimating the Payoff of Attending a More Selective College: An Application of Selection on Observables and Unobservables.” The Quarterly Journal of Economics. 117(4): 1491-1527.

Fleming, Jacqueline, 2002. "Who Will Succeed in College? When the SAT Predicts Black Student's Performance." The Review of Higher Education. 25(3):281-296.

Fleming, Jacqueline and Nancy Garcia, 1998. "Are Standardized Tests Fair to African Americans? Predictive Validity of the SAT in Black and White Institutions." Journal of Higher Education. 69(5):471-495. 
Hoffman, John L. and Katie E. Lowitzki, 2005. "Predicting College Success with High School Grades and Test Scores: Limitations for Minority Students." The Review of Higher Education. 28(4): 455-474

Jenks, Christopher and Meredith Phillips, 1995. The Black-White Test Score Gap. Brookings Institute Press, 1998. Fredrick E. Vars. and William G. Bowen, Chapter 13. "Scholastic Aptitude Test Scores, Race, and Academic Performance in Selective Colleges and Universities."

Kane, Thomas J. and Cecilia Elena Rouse, 1995. "Labor-Market Returns to Two- and Four-Year College." The American Economic Review. 85(3):600-614.

Levy, Frank and Richard J. Murnane, 1992. "U.S. Earnings Levels and Earnings Inequality: A Review of Recent Trends and Proposed Explanation.” Journal of Economic Literature. 20(3):1333-1381.

Light, Audrey and Wayne Strayer, 2000. "Determinants of College Completion: School Quality or Student Ability?" The Journal of Human Resources. 35(2): 299-332.

Loury, Linda and David Garman, 1995. "College Selectivity and Earnings.” Journal of Labor Economics. 13(2):289-308.

Knobler, Mike, 2008. "AJC Investigation: Many Athletes Lag Far Behind on SAT Scores." The Atlanta Journal Consitution. December 28, 2008.

NCAA Research Report Series 01. 1990-1997 http://www.ncaa.org/library/research/01Series/index.html

NCES, 1995. "Who Can Play? An Examination of NCAA's Proposition 16." National Center for Education Statistics. 95-763 
Pope, Devin G. and Jaren C. Pope, 2006. "Understanding College Choice Decisions: How Sports Success Garners Attention and Provides Information.” Working Paper

Profiles of American Colleges, 1997. Baron's Educational Series, Inc. $21^{\text {st }}$ Edition. New York.

Temp, George, 1971. "Validity of the SAT for Blacks and White in Thirteen Integrated Institutions." Journal of Educational Measurement. 8(4):245-251.

Tucker, Irvin B, 2004. “A Reexamination of the Effect of Big-Time Football and Basketball Success on Graduation Rates and Alumni Giving Rates.” Economics of Education. 23(6):655-661. 
Figure 1. Eligibility Scale for Potential Student-Athletes

Prior to Proposition 16

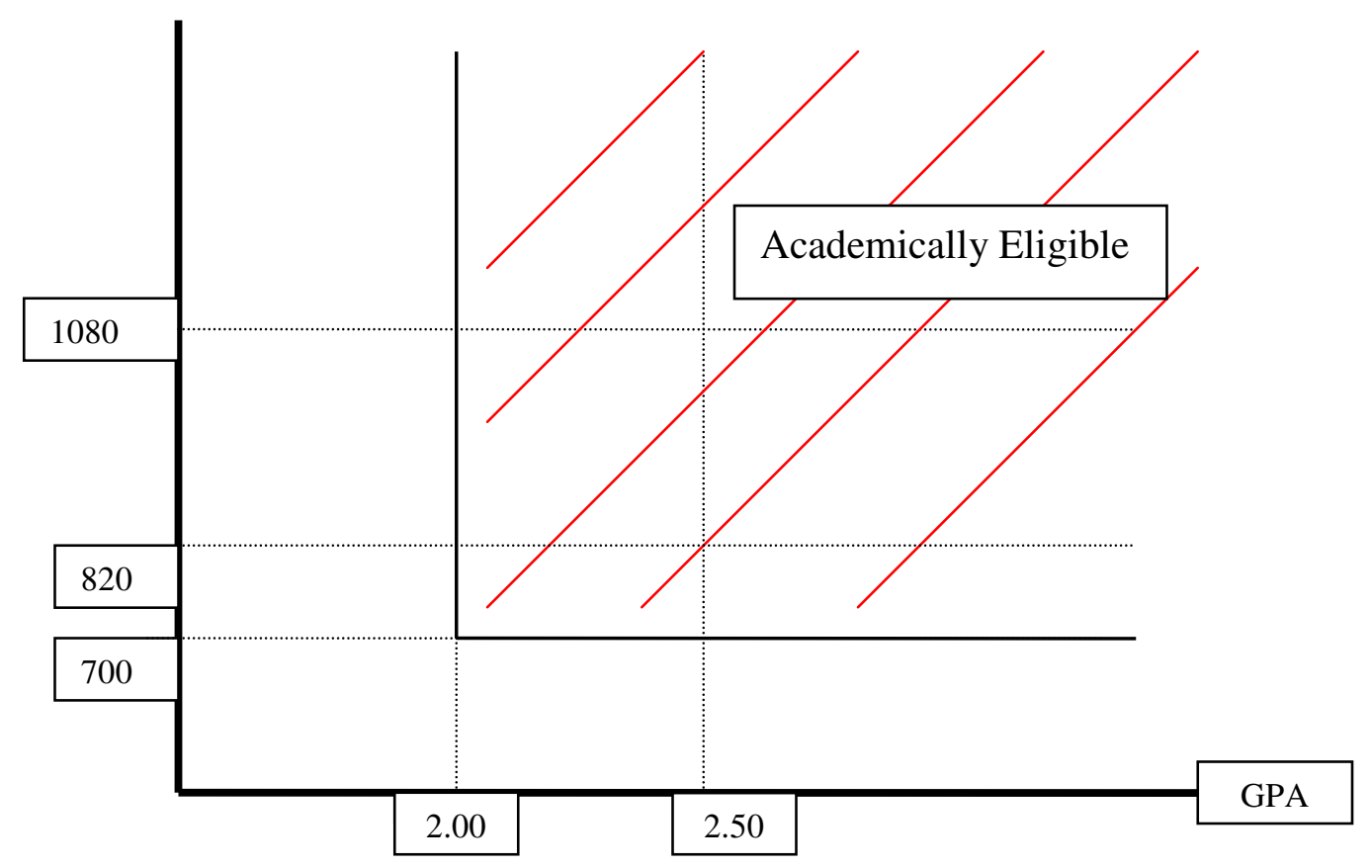

Sliding Scale of Proposition 16

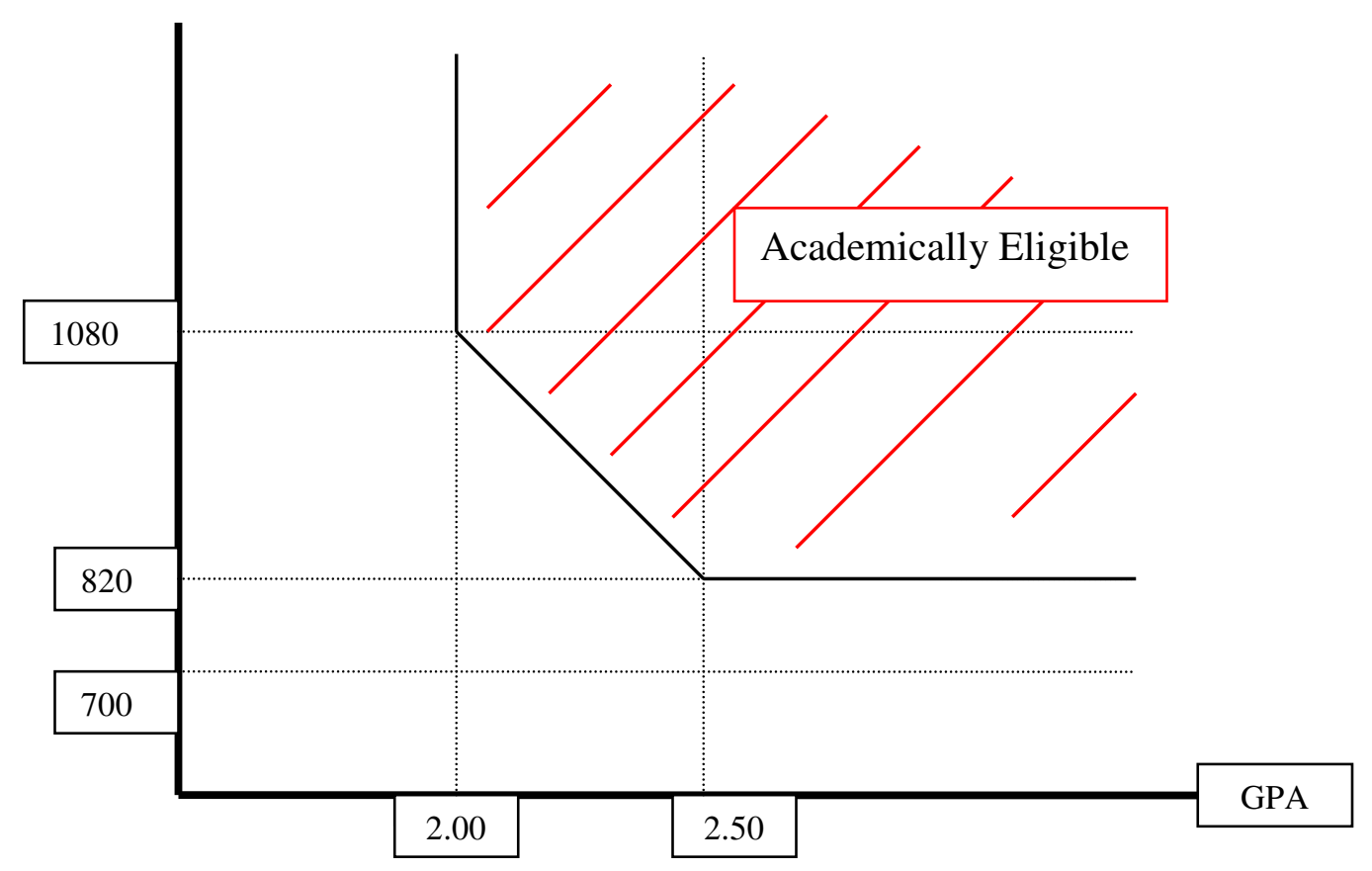


Figure 2. Enrollment Trends in the Number of Freshmen Student-Athletes

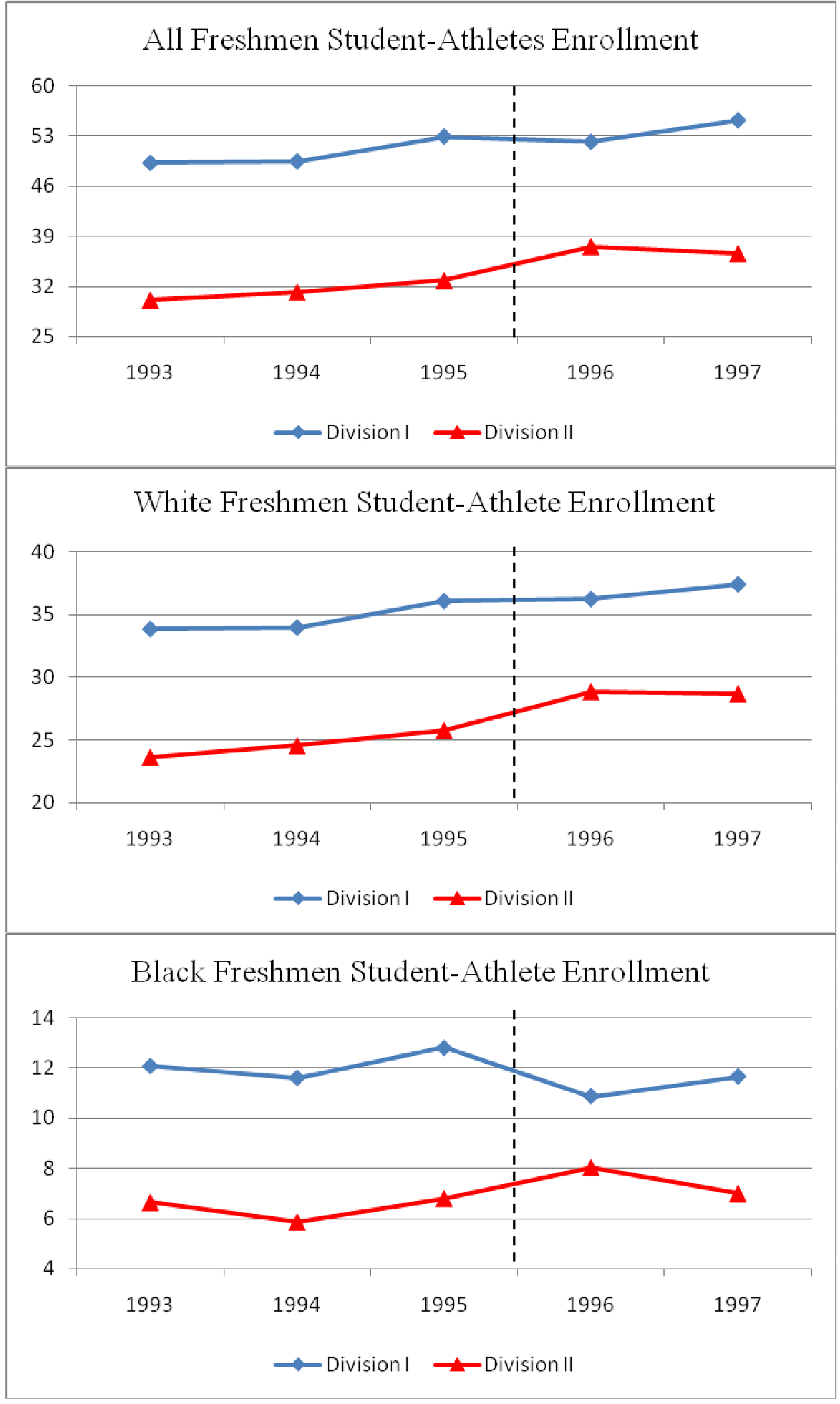


Figure 3. Graduation Rate Trends of Student-Athletes

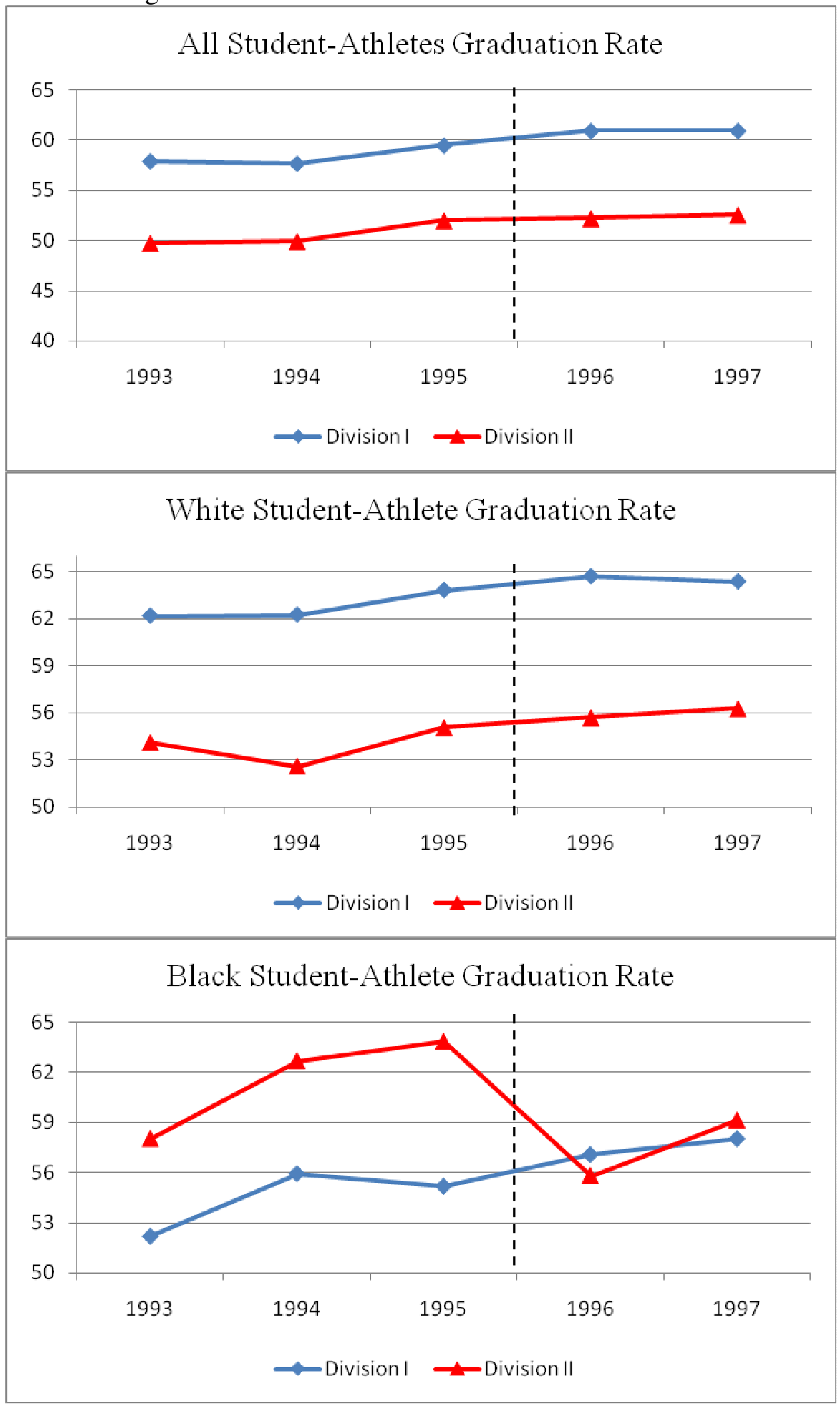


Table 1. Summary Statis tics of Enrollment

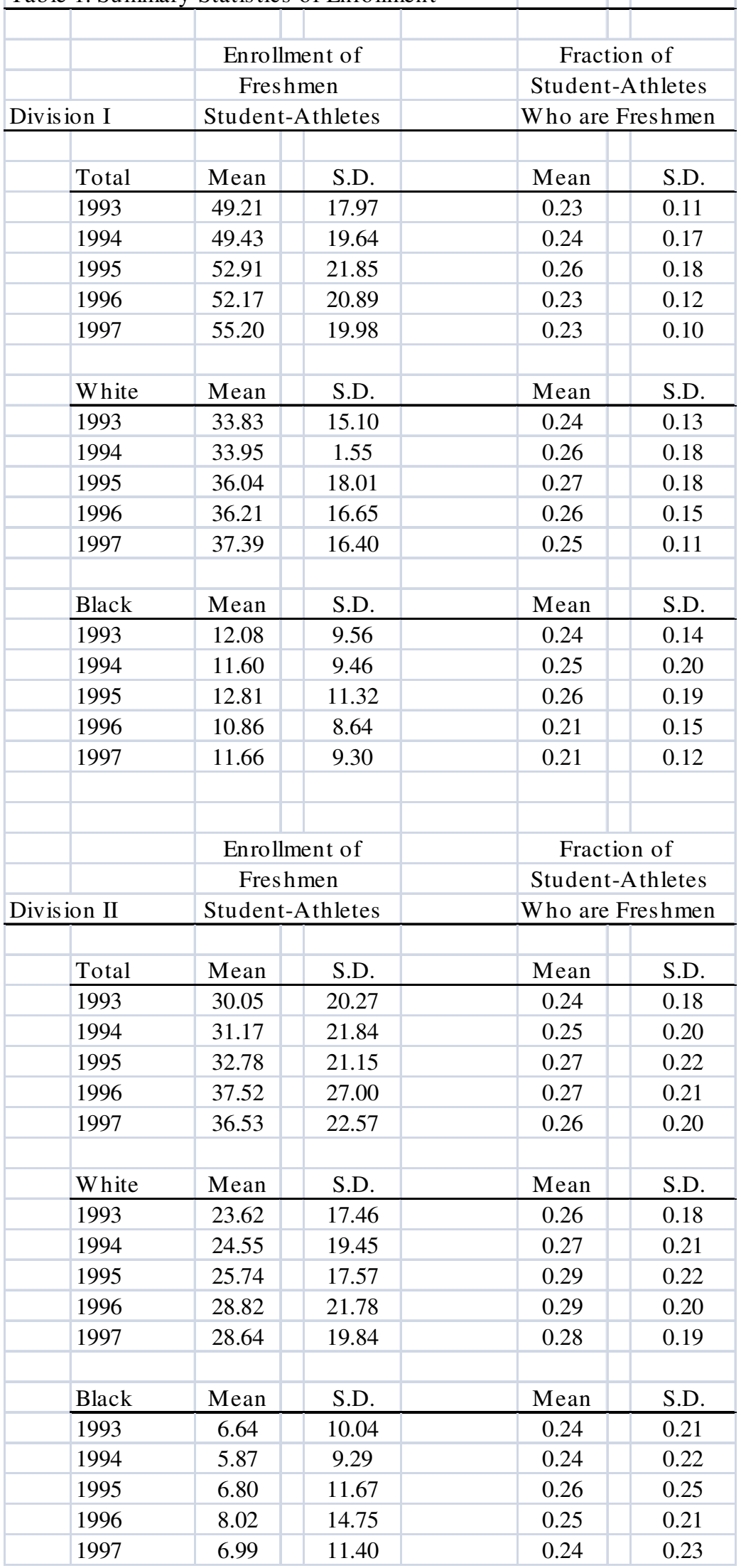




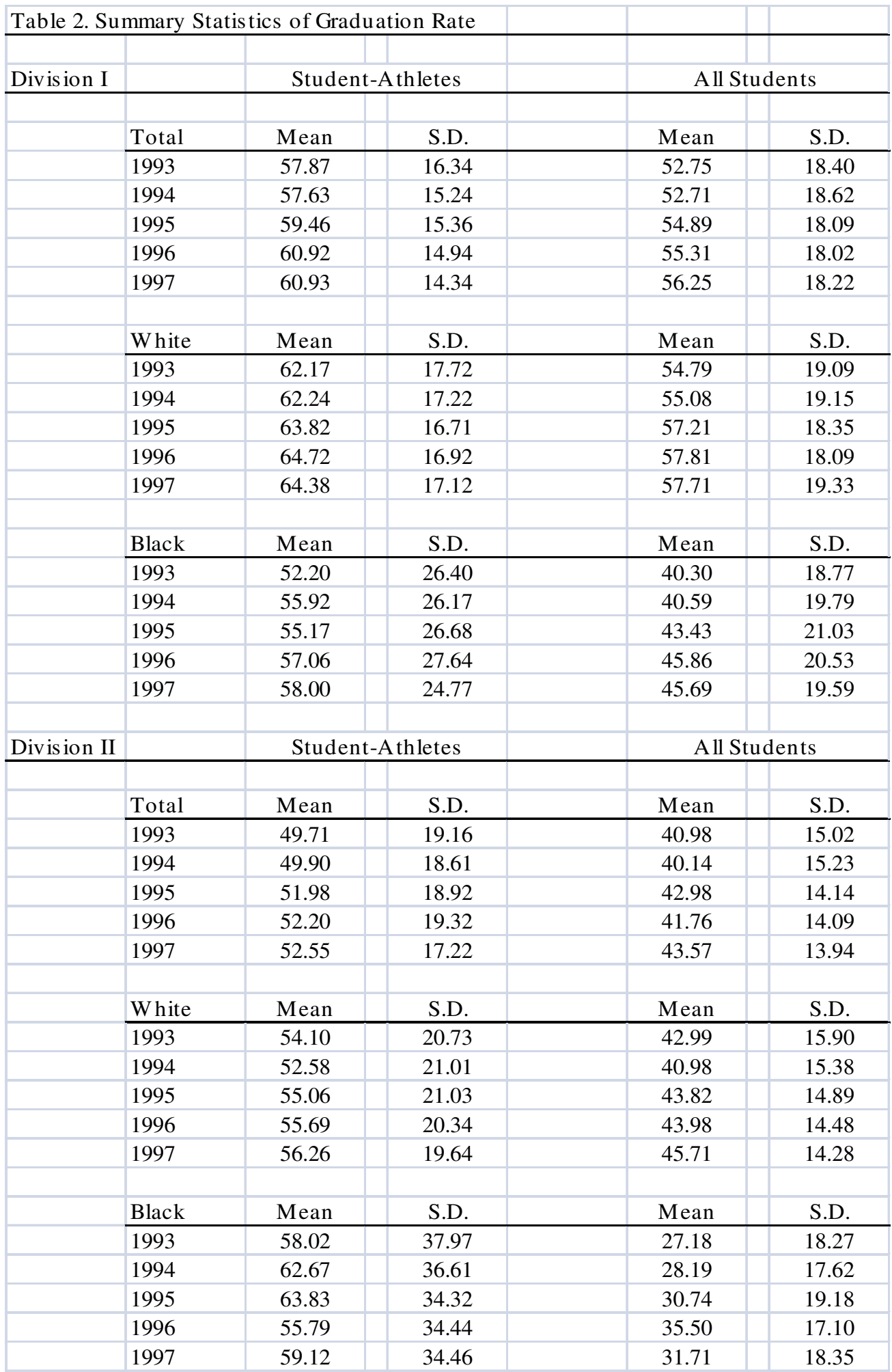


Table 3. Effect of Proposition 16 on Enrollment

\begin{tabular}{|l|c|c|c|}
\hline \multicolumn{2}{|l|}{ Dependent Variable is log (enrollment) } & \\
\hline Difference-in-Differences & & \\
\hline & & & \\
\hline Student-A thletes & Total & White & Black \\
\hline Div I & $0.611^{*} *$ & $0.478^{*} *$ & $0.915^{*} *$ \\
\hline & {$[0.044]$} & {$[0.060]$} & {$[0.082]$} \\
\hline Post & 0.062 & 0.075 & 0.133 \\
\hline & {$[0.039]$} & {$[0.051]$} & {$[0.070]$} \\
\hline Div I * Post & $-0.099 * *$ & $-0.122^{*} *$ & $-0.201^{*} *$ \\
\hline & {$[0.036]$} & {$[0.046]$} & {$[0.063]$} \\
\hline Constant & $3.143^{*} *$ & $2.829 * *$ & $1.185^{*} *$ \\
\hline & {$[0.044]$} & {$[0.058]$} & {$[0.072]$} \\
\hline time trend & yes & yes & yes \\
\hline & & & \\
\hline Obs ervations & 2790 & 2626 & 2505 \\
\hline & & & \\
\hline & & & \\
\hline Difference-in-Difference-in-Differences &
\end{tabular}

\begin{tabular}{|c|c|c|c|}
\hline & Total & White & Black \\
\hline \multirow[t]{2}{*}{ Div I } & $1.143 * *$ & $1.087 * *$ & $1.050 * *$ \\
\hline & {$[0.064]$} & {$[0.087]$} & {$[0.121]$} \\
\hline \multirow[t]{2}{*}{ Post } & $-0.088 * *$ & $-0.092 *$ & 0 \\
\hline & {$[0.024]$} & {$[0.042]$} & {$[0.062]$} \\
\hline \multirow[t]{2}{*}{ Div I * Post } & 0.051 & -0.023 & 0.044 \\
\hline & {$[0.026]$} & {$[0.048]$} & {$[0.063]$} \\
\hline \multirow[t]{2}{*}{ Ath } & $-2.807 * *$ & $-2.761 * *$ & $-2.191 * *$ \\
\hline & {$[0.056]$} & {$[0.063]$} & {$[0.078]$} \\
\hline \multirow[t]{2}{*}{ Ath * Div I } & $-0.532 * *$ & $-0.608 * *$ & -0.135 \\
\hline & {$[0.065]$} & {$[0.075]$} & {$[0.100]$} \\
\hline \multirow[t]{2}{*}{ Ath $*$ Post } & $0.178 * *$ & $0.179 * *$ & 0.118 \\
\hline & {$[0.040]$} & {$[0.041]$} & {$[0.070]$} \\
\hline \multirow[t]{2}{*}{ Ath $*$ Div I $*$ Post } & $-0.150 * *$ & $-0.099 *$ & $-0.245^{* *}$ \\
\hline & {$[0.043]$} & [0.049] & {$[0.079]$} \\
\hline \multirow[t]{2}{*}{ Constant } & $5.972 * *$ & $5.599 * *$ & $3.364 * *$ \\
\hline & {$[0.051]$} & {$[0.070]$} & {$[0.098]$} \\
\hline time trend & yes & yes & yes \\
\hline Observations & 5555 & 5222 & 4944 \\
\hline & & & \\
\hline
\end{tabular}

The third difference comes from differencing out enrollment of non-student-athletes

Robust standard errors in brackets

$*$ significant at $5 \%$;* significant at $1 \%$ 


\begin{tabular}{|c|c|c|c|}
\hline \multicolumn{3}{|c|}{ Dependent Variable is Fraction of Students } & \\
\hline who are Freshmen & & & \\
\hline \multicolumn{4}{|c|}{ Difference-in-Differences } \\
\hline & Total & White & Black \\
\hline \multirow[t]{2}{*}{ Div I } & -0.01 & -0.017 & 0.005 \\
\hline & {$[0.011]$} & {$[0.011]$} & {$[0.013]$} \\
\hline \multirow[t]{2}{*}{ Post } & -0.01 & -0.016 & -0.017 \\
\hline & {$[0.016]$} & {$[0.017]$} & {$[0.020]$} \\
\hline \multirow[t]{2}{*}{ Div I $*$ Post } & $-0.028 *$ & -0.011 & $-0.038 *$ \\
\hline & {$[0.013]$} & {$[0.015]$} & {$[0.017]$} \\
\hline \multirow[t]{2}{*}{ Constant } & $0.236 * *$ & $0.253 * *$ & $0.236 * *$ \\
\hline & {$[0.011]$} & {$[0.012]$} & {$[0.013]$} \\
\hline time trend & yes & yes & yes \\
\hline \multirow[t]{3}{*}{ Observations } & 2695 & 2530 & 2400 \\
\hline & & & \\
\hline & & & \\
\hline \multicolumn{4}{|c|}{ Difference-in-Difference-in-Differences } \\
\hline & & & \\
\hline & Total & White & Black \\
\hline \multirow[t]{2}{*}{ Div I } & -0.009 & -0.006 & -0.013 \\
\hline & {$[0.005]$} & {$[0.006]$} & {$[0.008]$} \\
\hline \multirow[t]{2}{*}{ Post } & -0.014 & -0.015 & $-0.034 * *$ \\
\hline & [0.008] & [0.008] & {$[0.010]$} \\
\hline \multirow[t]{2}{*}{ Div I $*$ Post } & 0.012 & 0.006 & $0.032 * *$ \\
\hline & {$[0.008]$} & {$[0.008]$} & {$[0.011]$} \\
\hline \multirow[t]{2}{*}{ Ath } & $0.054 * *$ & $0.073 * *$ & $0.039 * *$ \\
\hline & {$[0.010]$} & {$[0.010]$} & {$[0.012]$} \\
\hline \multirow[t]{2}{*}{ Ath $*$ Div I } & -0.001 & -0.011 & 0.018 \\
\hline & {$[0.012]$} & {$[0.013]$} & {$[0.015]$} \\
\hline \multirow[t]{2}{*}{ Ath $*$ Post } & 0.008 & 0.004 & 0.019 \\
\hline & [0.014] & {$[0.015]$} & {$[0.018]$} \\
\hline \multirow[t]{2}{*}{ Ath $*$ Div I $*$ Post } & $-0.040 *$ & -0.018 & $-0.070 * *$ \\
\hline & {$[0.016]$} & {$[0.017]$} & {$[0.020]$} \\
\hline \multirow[t]{2}{*}{ Constant } & $0.186^{* *}$ & $0.184 * *$ & $0.199 * *$ \\
\hline & [0.006] & {$[0.007]$} & [0.009] \\
\hline time trend & yes & yes & yes \\
\hline Observations & 5267 & 4943 & 4672 \\
\hline \multicolumn{4}{|c|}{ The third difference comes from differencing out } \\
\hline \multicolumn{3}{|c|}{ enrollment of non-s tudent-athletes } & \\
\hline \multicolumn{3}{|c|}{ Robust standard errors in brackets } & \\
\hline \multicolumn{3}{|c|}{$*$ significant at $5 \% ; * *$ significant at $1 \%$} & \\
\hline
\end{tabular}


Table 5. Enrollment of All Student-A thletes

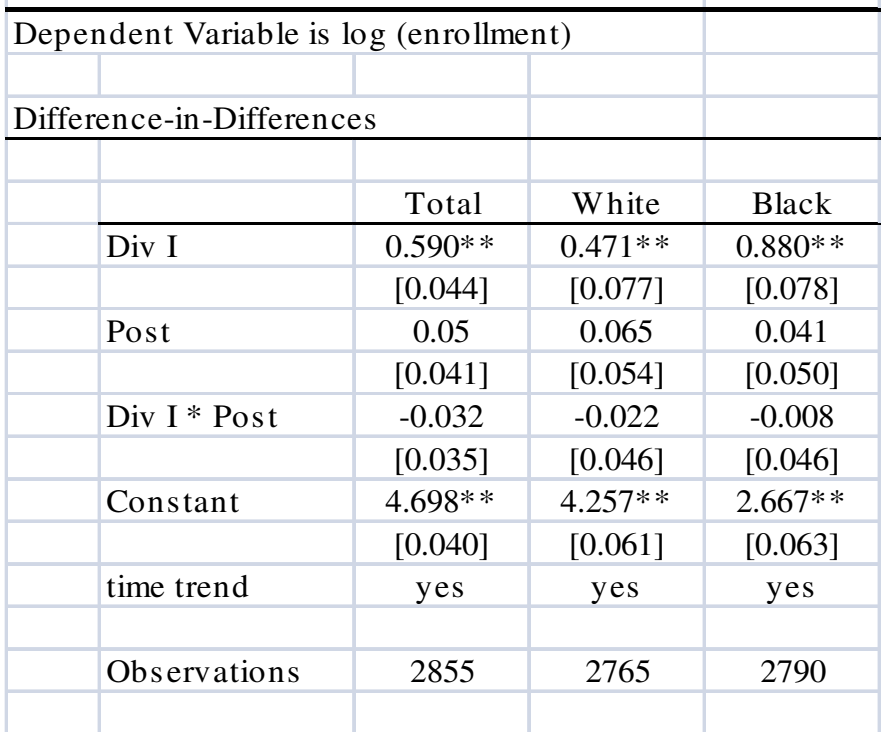

Robust standard errors in brackets

$*$ significant at 5\%; ** significant at $1 \%$

Table 6. Freshmen Enrollment of Non-Student-A thletes

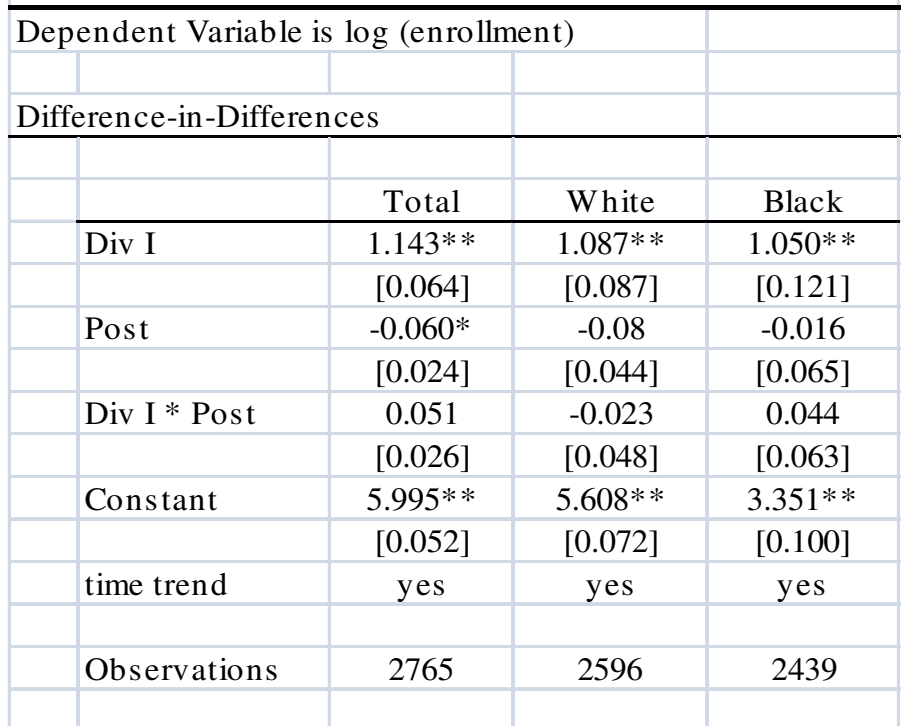

Robust standard errors in brackets

$*$ significant at $5 \% ; * *$ significant at $1 \%$ 
Table 7. Effect of Proposition 16 on Enrollment by Sport

\begin{tabular}{|c|c|c|c|}
\hline \multicolumn{3}{|c|}{ Average Marginal Effects of an Ordered Logit } & \multirow[b]{2}{*}{ Female Other Sports } \\
\hline Enroll 1 to 5 Freshmen & Football & Male Other Sports & \\
\hline Division I & $-0.124 * *$ & $0.015^{* *}$ & $-0.251 * *$ \\
\hline & [0.017] & {$[0.010]$} & [0.002] \\
\hline Post & -0.03 & 0.001 & $0.008^{*}$ \\
\hline & [0.024] & [0.022] & [0.011] \\
\hline Division $\mathrm{I} *$ Post & $0.044 * *$ & -0.016 & 0 \\
\hline & {$[0.016]$} & [0.018] & [0.010] \\
\hline Enroll 6 to 10 freshmen & Football & Male Other Sports & Female Other Sports \\
\hline Division I & $-0.111 * *$ & $-0.195 * *$ & $0.012 * *$ \\
\hline & [0.009] & {$[0.001]$} & {$[0.001]$} \\
\hline Post & -0.021 & 0.001 & $-0.038^{*}$ \\
\hline & [0.013] & {$[0.014]$} & [0.004] \\
\hline Division I $*$ Post & $0.034 *$ & 0.001 & -0.001 \\
\hline & {$[0.016]$} & {$[0.004]$} & {$[0.001]$} \\
\hline Enroll 11 to 15 Freshmen & Football & Male Other Sports & Female Other Sports \\
\hline Division I & $0.082 * *$ & $0.124 * *$ & $0.019 * *$ \\
\hline & [0.011] & {$[0.002]$} & [0.006] \\
\hline Post & 0.019 & -0.008 & $0.024 *$ \\
\hline & {$[0.015]$} & {$[0.002]$} & [0.001] \\
\hline Division $I *$ Post & $-0.026 * *$ & 0.01 & 0 \\
\hline & [0.009] & {$[0.001]$} & {$[0.001]$} \\
\hline Enroll 15 to 20 Freshmen & Football & Male Other Sports & Female Other Sports \\
\hline Division I & $0.100 * *$ & $0.042 * *$ & $0.168 * *$ \\
\hline & {$[0.007]$} & {$[0.007]$} & [0.001] \\
\hline Post & 0.021 & 0.002 & $0.002 *$ \\
\hline & [0.014] & [0.002] & [0.017] \\
\hline Division $\mathrm{I} *$ Post & $-0.033^{*}$ & 0.004 & -0.002 \\
\hline & [0.014] & {$[0.001]$} & [0.016] \\
\hline Enroll more than 20 Freshr & Football & Male Other Sports & Female Other Sports \\
\hline \multirow[t]{2}{*}{ Division I } & $0.052 * *$ & $0.014 * *$ & $0.052 * *$ \\
\hline & [0.004] & {$[0.001]$} & [0.008] \\
\hline \multirow[t]{2}{*}{ Post } & 0.011 & 0.005 & $0.003^{*}$ \\
\hline & [0.007] & {$[0.005]$} & {$[0.001]$} \\
\hline \multirow[t]{2}{*}{ Division $\mathrm{I} *$ Post } & $-0.019 *$ & 0.001 & 0.003 \\
\hline & [0.009] & {$[0.011]$} & {$[0.004]$} \\
\hline Controlled for time trend & yes & yes & yes \\
\hline Observations & 3208 & 4666 & 5256 \\
\hline \multicolumn{2}{|l|}{ Standard errors in brackets, } & & \\
\hline \multicolumn{2}{|c|}{$*$ significant at $5 \% ; * *$ significant at $1 \%$} & & \\
\hline
\end{tabular}



Table 8. Effect of Proposition 16 on Graduation Rates

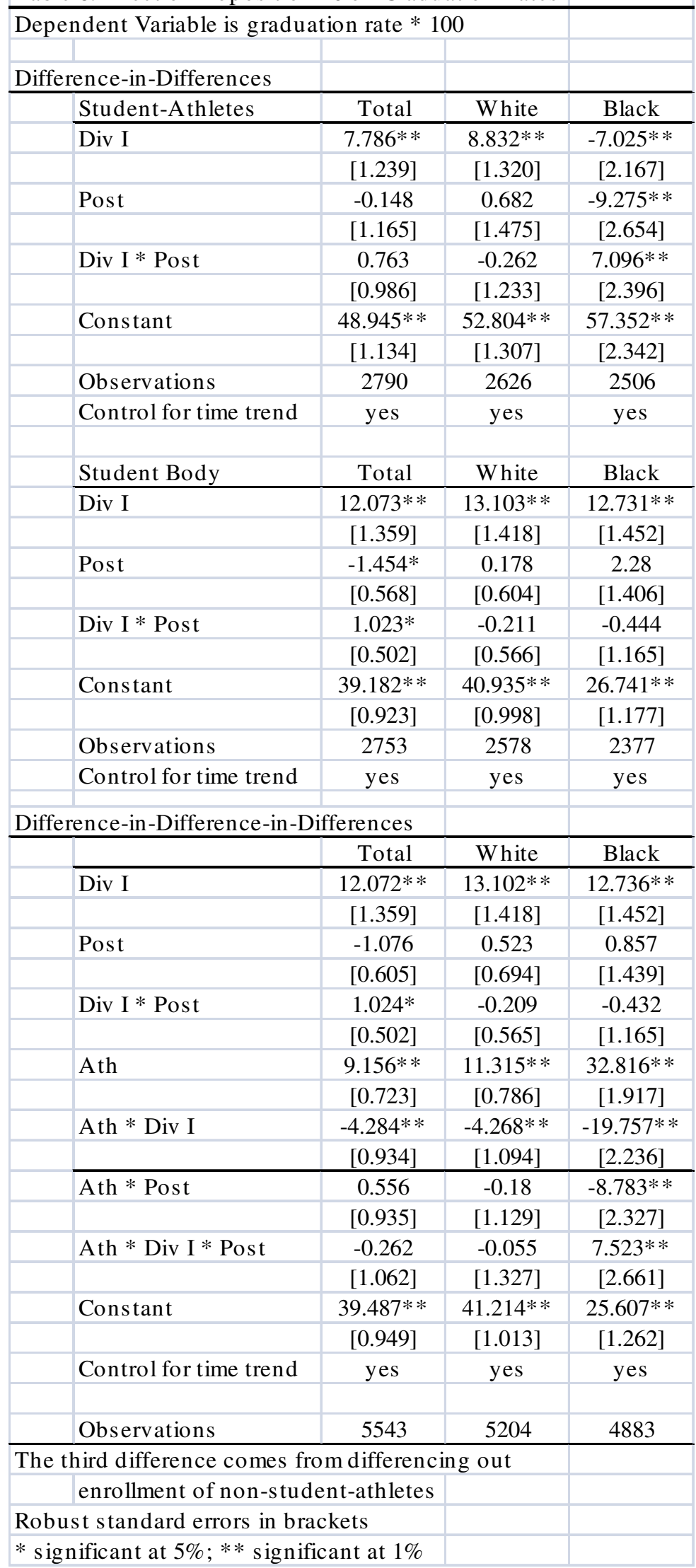

